ADALAH : Buletin Hukum \& Keadilan

Buletin Hukum \& Keadilan

@adalahuinjkt

\title{
Kedaulatan Rakyat Dalam Pemilihan Umum Langsung
}

\author{
Lazuardi Nuriman*
}

Kedaulatan rakyat dalam era demokrasi ini sudah seharusnya sudah menjadi milik rakyat sepenuhnya, karena saat ini pemilihan pemimpin negara atau pemimpin daerah sudah dipilih secara langsung oleh rakyat. Berbeda halnya dengan di masa orde lama dan orde baru, pemimpin kepala negara dan pemimpin daerah dipilih oleh wakil rakyat yang notabene ialah utusan partai politik, sebab itu kita harus mengembalikan kedaulatan rakyat sepenuhnya di tangan rakyat.

Menurut Sodikin pasal 1 ayat (2) UUD 1945 menempatkan rakyat sebagai pemilik kekuasaan tertinggi dalam penyelenggara negara. Pemilihan umum adalah mekanisme yang digunakan untuk memberikan mandat kepada penyelenggara negara sebagai pelaksanaan kekuasaan negara. Pemilihan umum yang digunakan untuk memberikan mandat kepada penyelenggara negara sebagai pelaksana kekuasaaan negara tersebut tanpa melihat bagaimana sistem diterapkan dalam pemilihan umum. Adapun, untuk menilai apakah pemilihan umum itu benarbenar telah dijadikan sebagai media pelaksana kedaulatan rakyat dapat dilihat dari sistem yang diterapkan (Sodikin, 2014: 106).

Proses amandemen UUD

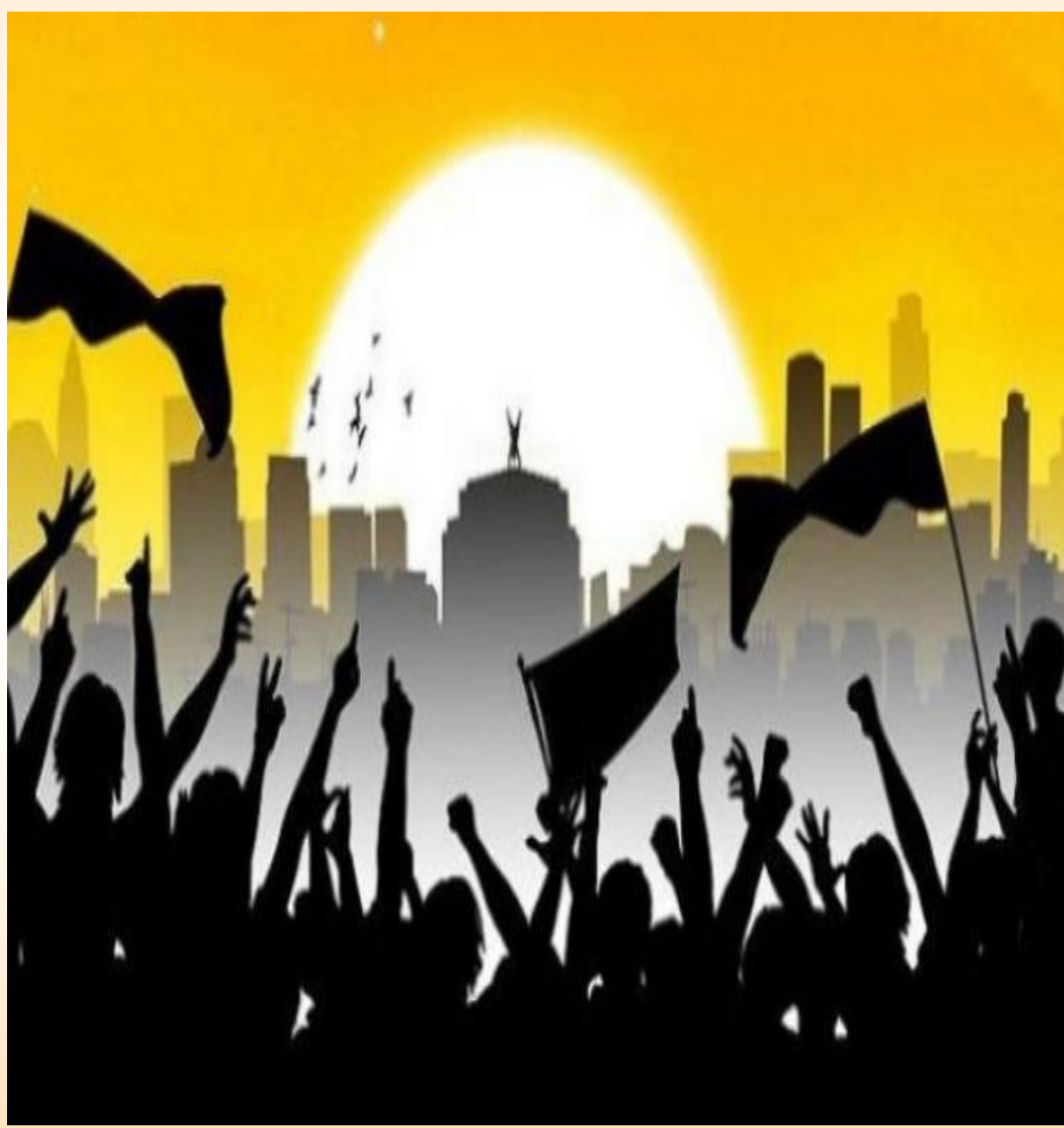

pemikiran baru tentang pelaksanaan kedaulatan rakyat. Pemikiran tersebut diwujudkan dengan diubahnya ketentuan pasal 1 ayat (2) UUD 1945, yang pada awalnya pasal 1 ayat (2) UUD 1945 berbunyi: "Kedaulatan adalah di tangan rakyat dan dilakukan sepenuhnya oleh Majelis Permusyaratan Rakyat", kemudian diubah menjadi "Kedaulatan berada di tangan rakyat dan dilaksanakan menurut undangundang dasar.

Namun, pemilihan umum yang diadakan secara langsung seharusnya menjadi wajah kemenangan rakyat di mata dunia, tetapi malah membuat bangsa ini tidak dapat bersaing dengan negara -negara maju. Mengapa? Karena prakteknya, pemilu ini hanya 
menjadi alat kekuasaan untuk mengambil suara terbanyak belaka, sehingga negara ini hanya sibuk mengurusi pemilu yang diadakan hampir sepanjang lima tahun sekali, dan melupakan upaya peningkatan daya saing pada sisi ekonomi, pendidikan,budaya dan sebagainya.

Sebagian kelompok anggota Dewan Perwakilan Rakyat ada yang kecewa dengan sistem pemilihan umum secara langsung, karena biaya untuk maju sebagai pemimpin negara atau daerah sangatlah mahal. Hal itu menyebabkan korupsi terjadi dimana-mana, sehingga mereka menginginkan pemilihan secara tertutup. Belum lagi pemilihan presiden yang sekarang hanya diikuti oleh minimal 3 pasang calon. Tentunya mereka hanya dipilih oleh beberapa partai politik yang ada di dalam Dewan Perwakilan Rakyat (DPR). Menurut Ahmad Farhan Subhi, menyatakan bahwa konstitusi Republik Indonesia menjamin adanya hak untuk memperoleh pengakuan, jaminan, perlindungan dan kepastian hukum yang adil serta perlakuan yang sama dihadapkan hukum [Pasal 28D ayat (1)], dan hak untuk memperoleh kesempatan yang sama dalam pemerintahan [Pasal 28D ayat (3)], serta hak untuk bebas dari segala bentuk diskriminasi [Pasal 28 I ayat

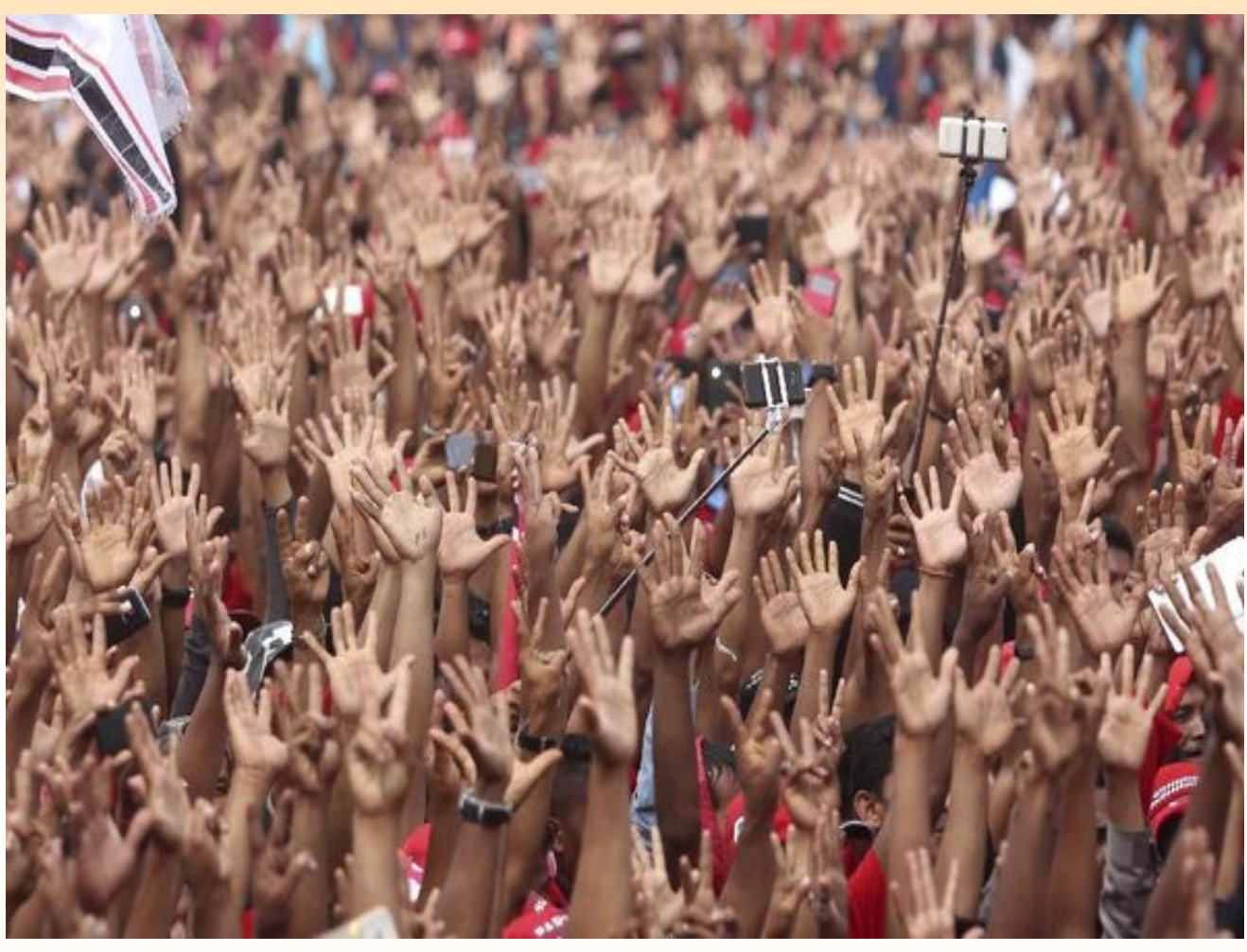

(2)]. Semua itu merupakan bentuk dari perwujudan kedaulatan rakyat yang telah digariskan dalam pasal 1 ayat (2) (Subhi, 2015: 340).

Menurut penulis kedaulatan rakyat dalam memilih pemimpinnya itu merupakan jalan akhir untuk mencapai demokrasi yang dicita-citakan, karena rakyat ikut berperan dalam membangun negara ini dengan memilih pemimpinnya sendiri. Jika ada yang salah dalam sistem pemilihan umum itu, maka bukanlah kesalahan demokrasi sepenuhnya, dan bukan malah mengambil hak rakyat dalam berdemokrasi. Seharusnya anggota DPR yang ingin mengubah pola pemilu ke sistem lama ingat saat masa reformasi yang mengakibatkan terjatuhnya kekuasaan Orde Baru dengan darah dan perjuangan. Buah perjuangan itu mengakibatkan rakyat dapat memilih pemimpinya sendiri, baik pemimpin negara maupun pemimpin daerah secara langsung, sehingga tercipta transparansi yang bisa dipantau oleh rakyat. Tugas Pemerintah dan DPR selanjutnya fokus memperbaiki demokrasi ini dengan menyelenggarakan pemilihan umum yang bersih jujur dan amanah tanpa mengambil harus mengambil alih kedaulatan rakyat. Bila pembenahan ini dapat dilakukan, demokrasi akan dapat menjaring pemimpin yang berjuang demi rakyat.[]

\section{Pustaka Acuan}

*Penulis adalah pengamat hukum di FSH UIN Jakarta dan sekaligus merupakan anggota Karang Taruna Kelurahan Sawangan Kota Depok

Sodikin, "Kedaulatan Rakyat dan pemilihan Kepala Daerah Dalam Konteks Undang-Undang Dasar Negara Republik Indonesia Tahun 1945", Jurnal Cita Hukum, Vol. 2, No. 1 Juni (2014).

Subhi, Farhan, "Pengusulan Pasang Calon Presiden dan Wakil Presiden Sebagai Peserta Pemilu Menurut Undang-Undang Pilpres," Jurnal Cita Hukum, Vol. 2, No. 2, Desember (2015).

'Adalah; Buletin Hukum dan Keadilan merupakan berkala ilmiah yang diterbitkan oleh Pusat Studi Konstitusi dan Legislasi Nasional (POSKO-LEGNAS), Fakultas Syariah dan Hukum UIN Syarif Hidayatullah Jakarta.

Penasehat: Prof. Dr. H. Abdul Ghani Abdullah, SH., Prof. Dr. H. A Salman Maggalatung, SH., MH. Pemimpin Redaktur: Indra Rahmatullah, Tim Redaktur: Nur Rohim Yunus, Fathuddin, Mara Sutan Rambe, Muhammad Ishar Helmi, Erwin Hikmatiar. Penyunting: Indah Furba, Hasin Abdullah. Setting \& Layout: Siti Anisaul Kamilah. 